\title{
Community Participation of Fishermen in Following Family Planning Program: A Case Study of Gender Relations in Village of KB Dusun Bagan Percut Sei Tuan
}

\author{
Osi Karina Saragih, Ratih Baiduri, Esi Emilia \\ Departement of Anthropology \\ State University of Medan \\ Medan, Indonesia \\ Email: osikarinasaragih67@gmail.com
}

\begin{abstract}
This study aims to determine the participation of fishermen in participating family planning programs in Percut sei Tuan and to know the gender relations built in fishing communities. The type of research used is descriptive qualitative with ethnography approach. The research technique is done by in-depth interview and participant observation. The results of this study indicate that the low participation of men in participating in family planning program, this is due to the strong construction of cultural values adopted by the fishermen community such as "many children a lot of sustenance", the child acts as a labor that helps the family, the child is a medium for improving the fate of the family, and bringing honor to the family. Gender relationship built in the fishing community in KB is still low because the KB is considered the domain of women, the low knowledge of women about family planning programs that cause women to be very vulnerable to receive the impact of the use of contraception, the condition where women can not make their own decisions if you want to participate in family planning program so have to ask the husband's permission.
\end{abstract}

Keywords - Community Participation; Gender Relations; Family Planning Program

\section{INTRODUCTION}

One of the most important problems faced by developing countries, such as in Indonesia is the population explosion. According to the former head of the National Population and Family Planning Agency Sugiri Syarief, Indonesia's population growth rate is currently around 1.49 percent yearly. That is, every year the number of population increases to 3.5 million to 4 million people ${ }^{1}$. The population explosion resulted in rapid population growth, due to the lack of knowledge and cultural patterns in the local community. To overcome these problems the Indonesian government has implemented the Family Planning Village (Village of KB) program. Village Family Planning Movement aims to control the rate of population growth and also to improve the quality of human resources.

Village of $\mathrm{KB}$ or abbreviated Village of $\mathrm{KB}$ is one of the National programs of BKKBN which aims to improve the quality of life of the community at the village level in order to realize a small family of quality, so this family of village can be used as a vehicle for community empowerment through various programs that lead to efforts changing attitudes, behaviors, and ways of thinking

\footnotetext{
${ }^{1}$ Manggiasih,Bunga.2011. Penduduk Indonesia Masukk Peringkat 4 Dunia. Diakses dari: http://www.tempo.co/read/news/2011/07/14/ 173346495 Penduduk-Indonesia-Masuk-Peringkat-4-Dunia. diakses pada tanggal: 30 September 2017.
}

(mindset) of society to a better direction, so that the formerly backward and backward village can be parallel to the other villages. Therefore it is reasonable to start the development of population from the periphery areas of the village, because the village is the forerunner of the formation of the village, and if the development of the whole village advanced, then despawn will go forward if all the villages are advanced then the country will certainly be advanced

Therefore, Village of $\mathrm{KB}$ is expected to be a miniature or a portrait of a village in which there is an integrated program of development of Population, Family Planning and Family Development synergized with sector-related development programs systematically and systematically. This is in accordance with the definition of Village of KB itself which is a unit of area of RW, hamlet or equivalent, which has certain criteria, where there is integrated KKBPK Program and related sector development systematically and systematically. So Village of $\mathrm{KB}$ as an effort to ground, revive, revitalize family planning programs to bring access to services to families and communities in an effort to actualize and to apply 8 family functions as a whole in the community.

Thus the activities undertaken in Village of $\mathrm{KB}$ are not only identical with the use and installation of contraception but is an integrated development program and integrated with 
various other development programs, so the container of Village of KB can be used as a vehicle for community empowerment through various programs that lead to efforts to change attitudes, behaviors, and ways of thinking (mindset) of society towards the better, so that the village that had been left behind and can be parallel to the other villages

The form of the program used in Village of KB to overcome the problem of population growth rate is Family Planning Program or Family Planning Program which is control program of population growth with jargon Two Children Enough. Based on Law no. 10 of 1992, Family Planning Program is an effort of government in raising awareness and participation of society through the maturation of marriage age, birth arrangement, family resilience coaching, and improvement of family welfare to realize small family, happy and prosperous ${ }^{2}$.

One of the areas that were promoted to Village of KB was Percut Village, Percut Sei Tuan Subdistrict, Deli Serdang Regency, specifically made by Bagan. This place is a place of research because this region is a coastal region that the majority of the population livelihood as fishermen. This place is always synonymous with poverty. This is because the traditional fishing life is entirely dependent on the catch obtained from the sea. The poor condition of traditional fishermen in Bagan Percut can be seen clearly through unfeasible housing conditions, uncertain fishermen's income, fishermen who have dropped out due to parents unable to send their children to school, the higher the number of births each year, while the quality of the source human power in the village is not supportive.

It's just that the village of KB that was carried in Bagan village Percut Village Percut Sei Tuan Deli Serdang District did not run smoothly even seem to fail. Even the rest of the activities of Village of $\mathrm{KB}$ is just a Poster and paintings are patterned Family Planning symbol. The scenery that is found in the village is children. The low public awareness of the maturation of marriage age is driven by several reasons such as customs, economics, and socio-culture, as well as the low number of active KB participants who will cause various population problems. Lack of public involvement in the socialization of Law Number 36 The year 2009 on Health that regulates reproductive and reproductive health so that the

\footnotetext{
2 Badan Pusat Statistik. 2012. "Perkembangan Beberapa Indikator Utama Sosial Ekonomi Indonesia". Jakarta. online http://www.bps.go.id/aboutus.php?booklet=1
}

community's understanding about the value of children has shifted from giving priority to the amount of attention to quality, especially education. The fact is that the value of children adopted by fishing communities dominates the economic value.

The problems that occur in fishing families are more due to social and cultural constructions that are understood and embraced by communities that are not based on the principle of gender equality. An understanding of the dominant, nondominant, superior-imperial subjects and the unequal distribution of roles between male family members (fathers, sons) and women (mothers, daughters) often position men more get privileges, while women as second class. Although in certain community groups (middle class and educated, for example) the relationships established between women and men are better, if it goes further, in most other societies, a balanced relation between women and men is still far of hope.

In addition, the division of labor by sex in fishing communities is based on existing cultural perceptions. In other words, the gender system is the social construction of the fishing community formed as an evolutionary outcome of a dialectical process between humans, the environment, and its culture. As a cultural product, gender systems are socially inherited from generation to generation. Based on the gender system of fishing communities, jobs related to the "sea" are "the domain of men", while the "land" is the "women" working sphere. The impact of this division of labor system is that women dominate in household economic affairs and important decision making in their households $^{3}$ (Kusnadi, 2001). Similarly with the family planning system, the perception of the fishermen community that the KB program is the domain of women.

Based on the above exposure, the authors are interested in conducting research entitled "Participation of Fishermen Community in Following Family Planning Program: Case Study of Gender Relations in Village of KB Dusun Bagan Desa Percut Sei Tuan"

\footnotetext{
3 Kusnadi.2001.Pangamba' Kaum Perempuan Fenomenal: Pelopor dan Penggerak Perekonomian Masyarakat Nelayan.Bandung: Humaniora Utama Press.
} 


\section{METHODOLOGY}

This research is descriptive with a qualitative approach which describes fisherman community participation in follow KB program. The location chosen as the research area is in Village of $\mathrm{KB}$ Dusun Bagan Percut Sei Tuan. This location was chosen because the birth rate was very high. The data were collected by searching the documents, in the form of books about Fishermen Society, Fishermen Society Culture, previous research and journal, and observation or observation on the life of Fisherman Society in Village of KB Dusun Bagan Percut Sei Tuan. Data collection techniques use participant observation techniques, free and in-depth interviews and literature studies.

\section{RESULT AND DISCUSSION}

The role of communities in implementing government programs, in an effort to establish an independent community and capable of prospering themselves respectively, is indispensable. In every government development effort, the role of society is needed because it is impossible for all activities to be undertaken by the government especially if the effort is aimed at the community itself and only the community can do it. Similarly, the role of communities in implementing family planning programs. The Family Planning Program as described already requires a high role from the community to engage in the success of the goals of family planning.

Involvement or participation is an important aspect of community development. Participation is one of the three elements of communityoriented development. Community participation is both a determinant and an indicator of the success of a government program or activity. As hard as any government effort to do development, if there is no public participation and no community support, then the success rate of development and sustainability of development programs will be different from the conditions if the community participates. ${ }^{4}$ For that can be said, that a program or activities undertaken by the government can be successful or successful if in the implementation of high community participation.

\footnotetext{
${ }^{4}$ Sunarti, Euis. 2012. "Partisipasi Masyarakat dalam Pembangunan Masyarakat”. Diakses dari: http://euissunarti.staff.ipb.ac.id/files/2012/03/ Dr.-Euis-SunartiPartisipasi-Masyarakat-dalam-Pembangunan-Masyarakat.pdf . pada tanggal : 7 november 2013. Pada pukul: 13:15 PM
}

Participation by Cohen and Uphoff (1977) ${ }^{5}$, participation is community involvement in the planner's process and decision-making on what is done, in program implementation and decisionmaking to contribute resources or cooperate in specific organizations or activities, share the benefits of program development and evaluation. ${ }^{6}$ Participation is an important aspect of generating independence and empowerment processes. Participation is used to improve the community's capacity. Not only in economic but also social, environmental and community-based development, where society is not an object but a subject in empowerment that feels and owns and encourages increased participation.

The involvement of fishermen community in family planning is realized through their role in supporting family planning and contraceptive use and planning the number of families. To realize the goal of the creation of the Small Family Family Family Prosperous Family. ${ }^{7}$ Forms of community participation of fishermen in family planning are divided into two, namely directly and indirect. 8

a. Directly

Participation is directly as a participant using one method or method of contraception.

\section{b. Indirect}

Indirect participation is to support every family planning activity and also as a motivator in accordance with knowledge of family planning.

Community participation in supporting family planning programs is still low. This is particularly evident in the participation of men / husbands. This is one of them due to the lack of access of men to the acquisition of information, family planning services, and reproductive health. According to UGM Center for Population and Policy Research Center (ISP) Issac Tri Oktaviatie, S.Ant, MSc, the lack of promotion or socialization of male family planning is due to family planning policy in Indonesia which is still focused on achieving female-female participants.

\footnotetext{
5 Cohen and Uphoff. 1977. Rural Development Participation. Cornel University. NewYork.

${ }^{6}$ Silviana, Septinia Eka, dkk. 2012. "Partisipasi Masyarakat dalam Pemerintahan Daerah". Diakses dari http://shintahappyyustiari.lecture.ub.ac.id/files/2012/11/KELOMPOK2.docx. Pada tanggal: 20 Oktober 2017. Pada pukul: 2:58 PM ${ }^{7}$ Omandhi-Odhiambo. Men's Participation in Family Planning Decision inKenya. Population Studies. 1997.

${ }^{8}$ Sukardi, S.Pd, 2011. "Partisipasi Pria dalam Keluarga Berencana". Diakses dari: http://sulbar.bkkbn.go.id/Lists/Artikel/DispForm.aspx?ID= $\underline{112 \& \text { Content TypeId=0x01003DCABABC04B7084595DA364423DE78 }}$ 97. Artikel BKKBN. Pada tanggal: 15 Oktober 2017, pada pukul: 08:40 AM
} 
In the above phenomenon, the reality of equality of gender relation in fisherman society still experiences obstacles. Culture is one of the factors that play a role in positioning women as the main actors in $\mathrm{KB}$ program activities. As stated by Kusnadi (2001) ${ }^{9}$ in his writings entitled Culture of Fishermen Society that: for fishermen society, culture is a system of ideas or cognitive system that serves as a "life guide", references patterns of social behavior, as well as a means to interpret and interpret various events that occur in the environment. And the patriarchal culture still looks very binding in the fishing community. Things like this are socialized from generation to generation in the community, boys follow the step of the father while girls follow the steps of the mother.

Women are still the main target of socialization of family planning program in the hope that the wife will communicate and negotiate the use of contraception (Alkon) to her husband. KB is considered the domain of women, the low knowledge of women about family planning programs that cause women to be very vulnerable to receive the impact of incorrect use of family planning, a condition where women can not make their own decisions if they want to join the family planning program so they have to ask the husband's permission. Cultural values and norms as a trigger unbalancing the role of women and men in fishing communities, especially in family planning programs. Many people assume that domestic work is the task of women so that reproductive work must be a responsibility that must be done by women.

Socio-cultural aspects of Indonesian society, he added, is also a factor causing low public awareness to play a role in the success of family planning programs. From the results of research conducted in Hamlet Bagan, it is known that people still perceive family planning is the responsibility of women. In addition, the use of condom contraceptives reduces comfort during sexual intercourse with a partner compared to the types of female contraceptives available. While the vasectomy method is still perceived as a form of castration and will reduce the strength of men. This erroneous view of vasectomy has given rise to a stigma against acceptors who are perceived by the surrounding community as men fearing their wives. Concerns also arise from

\footnotetext{
9 Kusnadi.2001.Pangamba' Kaum Perempuan Fenomenal: Pelopor dan Penggerak Perekonomian Masyarakat Nelayan.Bandung: Humaniora Utama Press.
}

women who think with vasectomy exactly will increase the chances of husbands to be unfaithful to the couple for not leaving a trace.

\section{CONCLUSION}

Family Planning Program conducted in Village of KB Dusun Bagan Percut Sei Tuan as an effort to overcome the problem of the increase in population growth rate with jargon Two Children Enough experienced obstacles. This is due to the low participation of fishermen community to participate in family planning program. The problems occurring within families of fishermen are caused by social and cultural constructions that are understood and embraced by communities that are not based on the principle of gender equality. So to increase public participation is not enough just by making agreement or commitment on paper, but need diligence, patience, togetherness and hard work between various parties, such as the community concerned, support from local government, traditional leaders, and BKKBN applied in concrete form through socialization, facilitating, assisting and nurturing a consistent and sustainable community.

\section{ACKNOWLEDGMENT}

The author would like to thank the graduate program of Medan State University, especially the lecturers of Social Anthropology Postgraduate, who gave me the opportunity to gain knowledge and guide me in making this paper.

\section{REFERENCES}

Badan Pusat Statistik. 2012. "Perkembangan Beberapa Indikator Utama Sosial Ekonomi Indonesia". Jakarta. online: http://www.bps.go.id/aboutus.php?bookl $\underline{\mathrm{et}=1}$

Cohen and Uphoff.. 1977. Rural Development Participation. Cornel University. NewYork.

Kinseng, Rilus A. 2014. Konflik Nelayan. Jakarta: Yayasan Pustaka Obor Indonesia.

Kusnadi.2001.Pangamba' Kaum Perempuan Fenomenal: Pelopor dan Penggerak Perekonomian Masyarakat Nelayan.Bandung: Humaniora Utama Press.

Manggiasih,Bunga.2011. Penduduk Indonesia Masukk Peringkat 4 Dunia. Diakses dari: http://www.tempo.co/read/news/2011/ 07/14/173346495/Penduduk-Indonesia- 
Masuk-Peringkat-4-Dunia. diakses pada tanggal: 30 September 2017.

Omandhi-Odhiambo. Men's Participation in Family Planning Decision inKenya. Population Studies. 1997.

Semedi, Pujo dan Jowono, H. 1998. Ketika Nelayan Harus Sandar Payung. Jakarta : KONPHALINDO

Silviana, Septinia Eka, dkk. 2012. "Partisipasi Masyarakat dalam Pemerintahan Daerah". Diakses dari : http://shintahappyyustiari.lecture.ub.ac.i d/files/2012/11/KELOMPOK-2.docx. Pada tanggal: 20 Oktober 2017. Pada pukul: 2:58 PM
Sukardi, S.Pd, 2011. "Partisipasi Pria dalam Keluarga Berencana". Diakses dari: http://sulbar.bkkbn.go.id/Lists/Artikel/D ispForm.aspx? ID $=112 \&$ Content TypeId $=0 \mathrm{x}$ 01003DCABABC04B7084595DA364423D E7897. Artikel BKKBN. Pada tanggal: 15 Oktober 2017, pada pukul: 08:40 AM

Sunarti, Euis. 2012. "Partisipasi Masyarakat dalam Pembangunan Masyarakat". Diakses dari: http://euissunarti.staff.ipb.ac.id/files/20 12/03/Dr.-Euis-Sunarti-PartisipasiMasyarakat-dalam-PembangunanMasyarakat.pdf . pada tanggal : 7 Oktober 2017. Pada pukul: 13:15 PM 